\title{
Depression-Let's Talk
}

\author{
Jyoti Priyadarshini ${ }^{1 *}$ and Alok Shrivastava ${ }^{2}$ \\ ${ }^{1}$ Department of Pathology, Gajra Raja Medical College, India \\ ${ }^{2}$ Consultant Orthopedician, District Hospital, State Health Services, India
}

Submission: April 20, 2017; Published: May 25, 2017

*Corresponding author: Jyoti Priyadarshini, Department of Pathology, Gajra Raja Medical College, India, Email: drpriyajyoti22@gmail.com

\section{Opinion}

Mental health is defined as a state of well-being in which every individual realizes his or her own potential, can cope with the normal stresses of life, can work productively and fruitfully, and is able to make a contribution to her or his community. The positive dimension of mental health is stressed in WHO's definition of health Health is a state of complete physical, mental and social well-being and not merely the absence of disease or infirmity» [1]. The theme for this year's World Health Day campaign is Depression. The slogan is: Depression: Let's talk [2].

Depression is a common mental disorder, characterized by sadness, loss of interest or pleasure, feelings of guilt or low selfworth, disturbed sleep or appetite, feelings of tiredness, and poor concentration for at least two weeks $[3,4]$.

\section{Target Population}

Depression can affect anyone whatever your age, sex, or social status. World Health Organization is paying particular attention to three groups that are disproportionally affected: adolescents and young adults, women of childbearing age (particularly following childbirth), and older adults (over 60s) [4].

Depression is a significant contributor to the globalburden of disease and affects people in all communities to affect 350 million people. The World Mental Health Survey conducted in 17 countries found that on average about 1 in 20 people reported having an episode of depression in the previous year. Depressivedisorders often start at a young age; they reducepeople's functioning and often are recurring. Forthese reasons, depression is the leading cause of disabilityworldwide in terms of total years lost due todisability. The demand for curbing depression andother mental health conditions is on the rise globally [5].

\section{Epidemiology}

Depression is one of the most common mental health problems. It is estimated that 16 to 20 out of 100 people will have depression or a chronic low mood (dysthymia) at least once in their lives. Women are affected more than men, and it is more common in older people [6]. About a quarter of medical students have depressive symptoms $[7,8]$.

\section{Types of Depression}

There are different types of depression, with different levels of severity. Some only arise under certain circumstances, for example after giving birth.Doctors differentiate between the following types of depression based on the symptoms and possible causes:
A. Unipolar Depression.
B. Dysthymia.
C. Seasonal Affective Disorder.
D. Postntal Depression.
E. Bipolar Depression [9].

\section{Pathophysiology}

Depression results from a complex interaction of social, psychological and biological factors. Depression can, in turn, lead to more stress and dysfunction and worsen the affected person's life situation and depression itself [10]. Depression is an interplay of imbalance between various chemicals like Stress hormones, Cytokines, Monoamines, Altered Glutamatergic and Gabaergic Neurotransmission ,Circadian Rhythm etc $[11,12]$. There is clinical and etiological heterogeneity of major depressive disorder, so it is difficult to elucidate its pathophysiology. Current neurobiological theories with the most valid empirical foundation and the highest clinical relevance are reviewed with respect to their strengths and weaknesses. The selected theories are based on studies investigating psychosocial stress and stress hormones, neurotransmitters such as serotonin, norepinephrine, dopamine, glutamate and gamma-aminobutyric acid (GABA), neurocircuitry, neurotrophic factors, and circadian rhythms. Because all theories of depression apply to only some types of depressed patients but not others, and because depressive pathophysiology may vary considerably across the 
course of illness, the current extant knowledge argues against a unified hypothesis of depression suggesting that depression is a clinically and etiologically heterogeneous disorder .Multimodality approach with antidepressants, including psychological and biological approaches, should be tailored for individual patients and disease states [13].

\section{Symptoms}

Physical symptoms are common in depression, and, in fact, vague aches and pain are often the presenting symptoms of depression. These symptoms include chronic joint pain, limb pain, back pain, gastrointestinal problems, tiredness, sleep disturbances, psychomotor activity changes, and appetite changes. A high percentage of patients with depression who seek treatment in a primary care setting report only physical symptoms, which can make depression very difficult to diagnose. Physical pain and depression have a deeper biological connection than simple cause and effect; the neurotransmitters that influence both pain and mood are serotonin and norepinephrine. Dysregulation of these transmitters is linked to both depression and pain [14].

While depression is the leading cause of disability for both males and females, the burden of depressionis 50\% higher for females than males (WHO 2008). In fact, depression is the leading cause of disease burden for women in both high-income andlow- and middle-income countries (WHO, 2008). Research in developing countries suggests thatmaternal depression may be a risk factor for poor growth in young children Rahman [15]. Depression is the leading cause of disease-related disability in women. Epidemiological studies have shown that the lifetime prevalence of a major depressive disorder in women $(21.3 \%)$ is almost twice that in men (12.7\%). This ratio has been documented in different countries and ethnic groups. Sex differences relating to depression vary with age, with male and female children showing similar incidence rates. National comorbidity data reveal that sex differences in prevalence first appear around the age of 10 years and persist until midlife, after which they disappear [16]. Improved methods of assessment and research design have established a robust and causal association between stressful life events and major depressive episodes [17].

\section{WHO Response}

Depression is one of the priority conditions covered by WHO's Mental Health Gap Action Programme (mhGAP). The Programme aims to help countries increase services for people with mental, neurological and substance use disorders, through care provided by health workers who are not specialists in mental health. The Programme asserts that with proper care, psychosocial assistance and medication, tens of millions of people with mental disorders, including depression, could begin to lead normal lives - even where resources are scarce $[18,19]$.

Depression is all prevailing, omnipresent associated with social stigma, yet it is treatable. It is an invisible illness with roots in the childhood .On an individual, community, and national level, it is time to educate ourselves and talk about depression and support those whoare suffering from this mental disorder.

\section{References}

1. http://www.who.int/features/factfiles/mental_health/en/

2. www.searo.who.int/india/mediacentre/events/world_health_day/ whd_2017/en/

3. www.who.int/topics/depression/en/

4. www.searo.who.int/india/mediacentre/events/world_health_day/ whd_2017/en/

5. www.who.int/mental_health/management/depression/who_paper_ depression_wfmh_2012.pdf

6. https://www.ncbi.nlm.nih.gov/pubmedhealth/PMH0072469/

7. Rotenstein LS, Ramos MA, Torre M3, Segal JB, Peluso MJ, et al. (2016) Prevalence of Depression, Depressive Symptoms, and Suicidal Ideation Among Medical Students. JAMA 316(21): 2214-2236.

8. https://en.wikipedia.org/wiki/Depression_(mood)

9. https://www.ncbi.nlm.nih.gov/pubmedhealth/PMH0072472/

10. http://www.who.int/mediacentre/factsheets/fs369/en/

11. https://www.scientificamerican.com/article/is-depression-just-badchemistry/

12. France CM, Paul LH, Ryan RP (2007) The Chemical Imbalance Explanation for Depression: Origins, Lay Endorsement, and Clinical Implications. Professional Psychology: Research and Practice 38(4): 411-420.

13. Hasler G (2010) Pathophysiology of Depression: Do we have any solid evidence of Interest to clinicians? World Psychiatry 9(3): 155-161.

14. Trivedi MH (2004) The Link Between Depression and Physical Symptoms. Prim Care Companion J Clin Psychiatry 6(1): 12-16.

15. www.who.int/mental_health/management/depression/who_paper_ depression_wfmh_2012.pdf

16. Noble RE (2005) Depression in women. Metabolism. 54(5 Suppl 1): 49-52.

17. Hammen C (2005) Stress and depression. Annu Rev Clin Psychol 1: 293-319.

18. http://www.who.int/mediacentre/factsheets/fs369/en/

19. www.who.int/mediacentre/factsheets/fs369/en/ 
(C) (i) This work is licensed under Creative Commons Attribution 4.0 License
Your next submission with Juniper Publishers will reach you the below assets

- Quality Editorial service

- Swift Peer Review

- Reprints availability

- E-prints Service

- Manuscript Podcast for convenient understanding

- Global attainment for your research

- Manuscript accessibility in different formats

( Pdf, E-pub, Full Text, Audio)

- Unceasing customer service

Track the below URL for one-step submission https://juniperpublishers.com/online-submission.php 